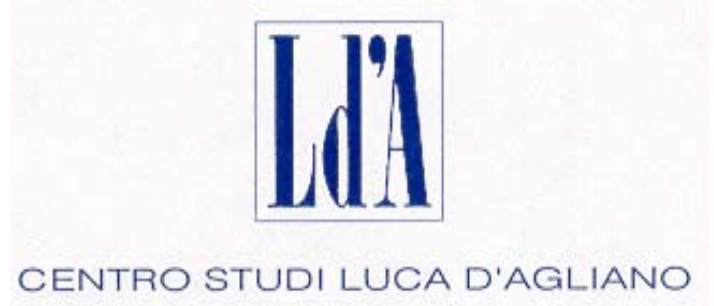

WWW.DAGLIANO.UNIMI.IT

\author{
CENTRO STUDI LUCA D'AGLIANO \\ DEVELOPMENT STUDIES WORKING PAPERS
}

N. 270

June 2009

\title{
Productivity and the international firm: dissecting heterogeneity
}

\author{
Davide Castellani* \\ Giorgia Giovannetti**
}

* University of Perugia

** University of Florence, European University Institute and Fondazione Manlio Masi-ICE 


\title{
Productivity and the international firm: dissecting heterogeneity
}

\author{
Davide Castellani \\ Università di Perugia \\ Giorgia Giovannetti \\ Università di Firenze, European University Institute and Fondazione Manlio Masi-ICE
}

February 2009

\begin{abstract}
Firms in competitive markets are more likely achieve higher productivity. Indeed a better performance of multinationals and exporters with respect to domestic firms has been documented in the literature. The sources of these premia have however largely remained a black box: standard theoretical models consider differences in productivity as the results of a random draw. Only recently models have acknowledged that in competitive environments, firms are more likely to adopt new technologies. This theoretical framework reconciles recent empirical work noting that productivity differences among firms can be explained by different managerial practices, I.T. and organizational capital. In this paper, using an original dataset on Italian firms, we show that the higher use of knowledge workers (such as R\&D workers, as well as workers in managerial and clerical occupations) explains some of the TFP premium of exporters and multinational firms. Our results suggest that TFP differences are not only the results in different constant in the production function between international and noninternational firms, but they rather reflect differences in the slopes of the production function. In fact, allowing for different returns to inputs between domestic and international firms, we explain all of the productivity premium and beyond. This is the result of the fact that multinational firms are both more capital intensive and exhibit higher returns to capital. Furthermore, we find that managers and capital are complements in the productivity of multinational firms. This is consistent with the idea that multinational firms have superior organizational capabilities and managerial practices.
\end{abstract}

JEL Classification: E22, L22, M2, O3

Key words: productivity, tfp, competition, management, mode of internationalization 


\section{Introduction}

Recent theoretical and empirical literature has widely documented a superior performance of international firms: multinationals are more productive than exporters, which in turn outperform purely domestic firms (Greenaway and Kneller, 2006, ISGEP, 2009, Mayer and Ottaviano, 2008). Most of the theoretical literature left these premia in a black box and considered them as the result of a random draw, which assigns different productivity to different firms, and thus induce the self-selection of some of them (the most productive) into export or FDI (Helpman, Melitz and Yeaple, 2004). Recent theoretical models have put forward the idea that firms may 'dress-up' before entering international markets, by investing in R\&D and thus increasing total factor productivity prior to start exporting (Costantini and Melitz, 2008). Schmitz (2005), among others, has pointed out that firms in a more competitive environments, such as the international markets (as opposed to smaller domestic markets) are more likely to adopt new technologies and achieve higher productivity than firms just having a monopoly power. Holmes et al (2008) show that this is due to the decrease in switchover disruption implicit in higher competitiveness. Other theoretical and empirical works have submitted that the crux of higher productivity of international firms, may be in the choice of the technology and the use of specific inputs, such as, skilled labor, I.T. capital or management practices, and in their complementarity. For example, Yeaple (2005) builds a model where firms, born identical, choose different technologies, characterized by different skill-intensities. Firm heterogeneity arises because firms endogenously choose to employ different technologies and then systematically hire different types of workers. Bloom, Sadun and Van Reenen (2007) show that the TFP is U.S. multinationals in the UK is mainly due to the higher returns to their I.T. capital, and claim that this pattern may be explained by the fact that the US firms organization allows them to use new technologies more efficiently. Black and Lynch (2001) show that workplace practices and I.T. had a significant impact on TFP of a sample of US firms over the 1987-1993 period. Bloom and Van Reenen (2007) report a similar impact of management practices on productivity from 732 medium-sized manufacturing firms in the US, France, Germany and the UK. Bresnahan, Brynjolfsson and Hitt (2002) find positive effects of a measure of organizational capital (constructed from survey data as a linear combination of questions on team working and workers' 
authority) on productivity both directly and through its interaction with capital. Similarly, Brynjolfsson and Hitt (2002) find a positive and sizeable effect of information technology on productivity over long periods (5-7 years) in a sample of US firms and claim that the observed contribution of computerization is accompanied by relatively large and time-consuming investments in complementary inputs, such as organizational capital, that may be omitted in conventional calculations of productivity. In this paper we explore the black box. We test whether, and to what extent, heterogeneity in firms' TFP can be attributed to the fact that these firms are more innovative and use more knowledge workers (such as R\&D workers, as well as workers in managerial and clerical occupations), or if this is rather a matter of how they use their inputs. This hypothesis is linked to the fact that workers and capital may be more productive in international firms, either because of their higher quality, or due to the firm superior managerial practices and organizational capital. In other words, we dissect heterogeneity in productivity associated with firms' internationalization, by distinguishing to what extent differences in productivity are due to (i) differences in $\mathrm{TFP}^{1}$, or (ii) to how firms choose their production function and how productive are individual inputs ${ }^{2}$.

Using an original dataset of Italian firms ${ }^{3}$, we estimate firms TFP using different parametric methods ${ }^{4}$ and we consistently find sizable TFP premia for international firms (exporters and multinationals). Our results are robust to estimation methods. These premia substantially shrink if we take into account the higher use of knowledge workers (such as managers and other white collar employees) in international firms, but they still remain positive and significant (especially for multinationals). However, if we allow for heterogeneity in the slope of the production function, multinationals exhibit a significantly higher return to capital and TFP premia for international firms vanish. We interpret this as evidence that heterogeneity across firms with different international exposure is not in the constant, but rather in the slope of the production functions. We estimate a flexible translog specification and find evidence of complementarity between managers and physical capital, especially among exporters and multinational firms.

\footnotetext{
${ }^{1}$ We measure differences in TFP as differences in the constant of the production function

${ }^{2}$ We consider the possibility of different slopes of the production function

${ }^{3}$ The dataset, which matches and merges two different datasets, is described in section 4 and, more in detail, in the data appendix.

${ }^{4}$ We use methods ranging from OLS to Olley-Pakes and Levinshon-Petrin, fixed effect or GMM
} 
The rest of the paper proceeds as follows: in section 2 we set our empirical strategy. Section 3 describes the data. Section 4 presents the main results and section 5 concludes.

\section{Heterogeneity in the constant or in the slope?}

Firm productivity can be modelled in the context of a production function such as the following:

$$
Y_{i t}=A_{i t} \cdot F_{i t}\left(K_{i t}, L_{i t}\right)
$$

where $\mathrm{Y}, \mathrm{K}$ and $\mathrm{L}$ denote firm output, physical capital and labor used in production, $\mathrm{F}($.) is a generic production function which transforms inputs (K and $\mathrm{L})$ into outputs $(\mathrm{Y})$ and A is total factor productivity, defined as an Hicks-neutral technical progress, which acts as a shifter of the production function. In principle, both $\mathrm{F}($.$) and \mathrm{A}$ need not be the same across firms $(i)$ and over time $(t)$.

Assuming a Cobb-Douglas specification for $\mathrm{F}($.$) and taking logs we can write$ (lowercase denote natural $\log$ )

$$
y_{i t}=\beta_{i t}^{l} l_{i t}+\beta_{i t}^{k} k_{i t}+a_{i t}
$$

To focus on differences in TFP across international and non international firms, we specify

$$
a_{i t}=\delta I_{i}+\widetilde{a}_{i t}
$$

where $\mathrm{I}$ is an indicator variable which takes value 1 if firm $i$ is internationalised ${ }^{5}$. The parameter $\delta$ captures differences in TFP across international and non-international firms. Or, in other words, it allows the production function of international and noninternational firms to have different constants (heterogeneity in the constant). By adding additional firm-level variables to this equation (such as measures of $R \& D$ and innovation or organizational characteristics of the firm), we may eventually be able to explain all the difference in the constants among firms.

If we want to estimate equation (3) parametrically, we need to assume $\beta_{i t}^{l}=\beta^{l}$ and $\beta_{i t}^{k}=\beta^{k}$. This yields the following estimating equation:

\footnotetext{
${ }^{5}$ We assume that firms cannot change status over the time period. This assumption can easily be relaxed, but we maintain it as in the subsequent empirical analysis we cannot identify whether firms change international status over time.
} 


$$
y_{i t}=\beta^{l} l_{i t}+\beta^{k} k_{i t}+u_{i t}
$$

where

$$
u_{i t}=\delta I_{i}+\widetilde{\beta}_{i t}^{l} l_{i t}+\widetilde{\beta}_{i t}^{k} k_{i t}+\widetilde{a}_{i t}=\delta I_{i}+\widetilde{u}_{i t}
$$

The parameters $\widetilde{\beta}_{i t}^{z}=\beta_{i t}^{z}-\beta^{z}$ with $z=l$ and $k$, reflect the heterogeneity of firm $i$ in its returns to capital and labor with respect to the average return to inputs among all firms in the sample, while $\widetilde{a}_{i t}$ is a measure of a firm ability to increase the returns of both inputs, i.e. the total factor productivity (TFP). Plugging (5) into (4) and estimating the resulting equation, $\delta$ may not only capture differences in the constant of the production function $\left(\widetilde{a}_{i t}\right)$, but also heterogeneity in the slopes $\left(\widetilde{\beta}_{i t}^{z}\right)$. The extent of this bias would depend on the correlation between the $\widetilde{\beta}_{i t}^{z}$ 's and the internationalisation status (I). For example, if international firms use more advanced physical or IT capital, they would exhibit higher $\widetilde{\beta}_{i t}^{k}$. If we do not allow for different slopes of the production function across firms, we may mix higher TFP, with higher return to capital. To some extent, this amounts to mixing disembodied with embodied technical change.

One simple way to account for this heterogeneity is to estimate the production function on sub-samples of firms (or estimating different parameters for different groups of firms using interactions). In doing so, we reduce the remaining heterogeneity in parameters $\widetilde{\beta}_{i t}^{l}$ and $\widetilde{\beta}_{i t}^{k} \cdot{ }^{6}$

\section{Data}

Our empirical analysis is carried out using an original dataset obtained by matching and merging data from the $8^{\text {th }}$ and $9^{\text {th }}$ waves of a survey carried out by Capitalia and the ICE-Reprint dataset.

The two Capitalia surveys cover respectively years 1998-2000 and 2001-2003 and provide detailed qualitative and quantitative information on a large sample of Italian manufacturing firms. In this paper we exploit partially the information contained

\footnotetext{
${ }^{6}$ Alternatively, assuming perfect competition in labour and product markets, one could compute labour elasticity as the wage share in value added. Imposing constant returns to scale, the elasticity of capital is the complement to one. This, sometimes known as the index number approach, has the advantage of allowing maximum heterogeneity in production functions, but it requires stronger assumptions and it is subject to measurement errors (Van Biesenbrock, 2007).
} 
in the data, by focusing on firms' characteristics such as the innovativeness ${ }^{7}$, investment in machinery and equipment as well as in ICT, R\&D intensity, the educational profile of the workforce ${ }^{8}$, and the occupational profile (managers, clerks and production workers). Balance sheet information are also available (with some missing data) for the 19982003 sample period. If we confine attention to 2001-2003, we have information for the 4,277 firms included in the $9^{\text {th }}$ survey; out of this sample, 2,097 firms are also in the previous survey (the one covering the period 1998-2000) and can thus be observed over a six-year period. As shown in Table 1, due to missing values and cleaning procedures ${ }^{9}$, we end up with up to 16,794 firm-year observations (10,950 when considering only firms included in both surveys).

\section{INSERT TABLE 1 HERE}

The Capitalia Survey, though allowing us to distinguish domestic firms from firms selling part of the production abroad through exports, does not provide data on the internationalization of production. Hence, we also merge information from the ICEReprint dataset which allows us to identify Italian multinationals ${ }^{10}$. Both indicator of international status (i.e. being an exporter and/or being a multinational firm) are referred to $2001^{11}$.

\section{INSERT TABLE 2 HERE}

As illustrated in Table 1, on average, about 9\% of firms are multinationals, $65 \%$ are non-multinational exporters, while one-forth of the firms are not international

\footnotetext{
${ }^{7}$ Innovativeness is captured by three dummies taking value 1 if firms carried out product, process and organizational innovation over the past three years

${ }^{8}$ The survey has data on the share of workers with a bachelor degree 'laurea' or with a secondary school diploma

9 We have dropped 'anomalous' firm-year observations. 'Anomalous' observations have been defined as values for inputs and output which exceeded the median for each firm by three times or were lower than one-third of the median.

${ }^{10}$ See the Data Appendix for a more precise description of the ICE-Reprint dataset.

${ }^{11}$ For the sub-sample of firms included both in the $8^{\text {th }}$ and $9^{\text {th }}$ survey, information on the export status in 1998 was also available. Given the high degree of persistence in exporting $(92 \%$ of firms exporting in the $8^{\text {th }}$ survey are exporters also in the $9^{\text {th }}$ ), we choose to use a time invariant indicator for the export status. Therefore, we identify the international status of the sample firms in 2001 and assume it as time-invariant throughout the period.
} 
(purely domestic firms). Table 3 provides information on some basic characteristics of our sample, according to the international status of the firms.

\section{INSERT TABLE 3 HERE}

These descriptive statistics confirm that, firms rank according to their degree of internationalization: multinationals are the largest, the most productive, have a higher capital intensity, are the most likely to be limited company (ltd), to introduce innovations, to invest in machinery, equipment and ICT, have the highest share of workers engaged in R\&D, and employ more managers and clerks ${ }^{12}$. Non-international (domestic) firms, on the other hand, have lower values for all of these characteristics, while non-multinational exporters stand in between. Hence, the international status seems to be positively correlated with productivity and with a number of other characteristics. In the following, we test whether differences in productivity associated with a different international status persist once sector, region, size and time effects are accounted for. Furthermore, we investigate whether differences in innovation, investment behavior, legal status, $R \& D$ and managerial intensity can explain such productivity premia.

\section{Results}

\subsection{Heterogeneity in the constant: evidence from a two-inputs production function}

In order to compute differences in TFP across international and non-international firms, we first estimate $\hat{\beta}^{l}$ and $\hat{\beta}^{k}$ from a Cobb-Douglas production function where output is measured by the log of value added (deflated using 2-digit production price indexes) and inputs are the log of tangible fixed assets (net of depreciation and deflated using the price index of machinery and equipment) and the log of the number of employees ${ }^{13}$.

\footnotetext{
12 This is consistent with the theoretical model of Holmes et al (2008) where they claim that the international environment is more competitive and this makes firms more willing to innovate because their losses (in terms of foregone profits) are lower.

${ }^{13}$ In section 3 we developed and empirical model where TFP differentials are computed in the same regression where the production function parameters are estimated. In the following empirical analysis we choose to follow a two-step procedure, where we first estimate TFP as the residual of a production
} 
Following Van Biesenbroeck (2007a, 2007b), we use several estimation methods. In particular, we estimate the model using (i) a standard OLS, (ii) OLS with sector-time, region and size class dummies (OLS-D), (iii) Olley-Pakes (OP) and (iv) LevinsohnPetrin (LP) semi-parametric methods, (v) fixed-effects (using within-group transformation (FE), (vi) as well as one-year (DIF1) and (vii) three-years differences (DIF3)), and two specifications allowing for autocorrelated TFP, using (viii) a random effect model with AR1 disturbances (RE-AR1), and (ix) a dynamic model estimated using GMM-DPD.

\section{INSERT TABLE 4 AND FIGURE 1 HERE}

Figure 1 and Table 4 report the $\hat{\beta}^{l}$ and $\hat{\beta}^{k}$ estimated from the different methods. As it is well known in the literature (for a recent discussion see Van Biesenbroeck, 2007a), OLS tend to give upward biased estimates (returns to scale are well above one) due to the correlation between input use and productivity, while fixed-effects models give downward biased due to limited within-group variation (especially in short panels) which exacerbates measurement errors. In between these two extremes are all the other parametric and semi-parametric methods. Table 5 provide some basic statistics on TFP obtained as

$$
T \hat{F} P_{i t}=\exp \left(y_{i t}-\hat{\beta}^{l} l_{i t}-\hat{\beta}^{k} k_{i t}\right)
$$

As one would expect, TFP levels change according to the estimation method: the higher the returns to scale, the lower the estimated TFP. This can be easily explained since higher estimated returns to scale means a higher contribution of inputs to output variation and corresponding lower unexplained variation. Despite the different estimated levels of TFP, Table 6 shows that the different methods yield remarkably high correlated TFP measures (as in Van Biesenbroeck, 2007). Apart from the low correlation between the fixed-effect and the OLS measures, all measures are generally

function and then estimate this residual on I and other firm-level variables. This is needed in order to be able to apply a wide array of choices in the estimation of the production function. For example, accommodating firm-level characteristics in OP or LP may be rather problematic. 
correlated at $90 \%$ or more. For the sake of brevity, the following analysis will be carried out using TFP only OLS-D, OP, LP and RE-AR1 estimators ${ }^{14}$.

\section{INSERT TABLE 5 AND 6 HERE}

With these set of estimates of firm-level TFP, we can now explore differences in TFP between international firms (identified as exporters and multinationals) and noninternational firms. We regress firm $(\log )$ TFP on two dummies taking value 1 for multinational firms and non-multinational exporters (the baseline category are nonexporting firms) and a vector of controls, which include dummies for sector and time, firm location (regions), size class, and other firm characteristics. Results are reported in Table 7.

\section{INSERT TABLE 7 HERE}

The estimates reported in column $(1,4,7,10)$ are consistent with the descriptive statistics of Table 3, and support the idea that Italian multinationals and nonmultinational exporters are more productive (in terms of TFP) than domestic nonexporting firms, after controlling for sector, region, size and time differences. The magnitude if this premium is also rather consistent across methods: for multinational firms it goes from $16 \%$ using OLS-D to $23 \%$ using $\mathrm{OP}^{15}$; for exporters it varies from $6.5 \%$ (with OLS-D) to $7.9 \%$ (with OP). We then control for further sources of heterogeneity in firm productivity, which can be correlated with the international status and report the results in subsequent columns. In columns $(2,5,8,11)$ we add a dummy indicating whether the firm is incorporated, three dummies taking value one if the firms has introduced product, process or organizational innovation over the past three years, two dummies capturing investments in machinery and equipment and in ICT, and the share of employees engaged in R\&D activities. The magnitude of the coefficients on the multinational firm and non-multinational exporter dummies are slightly lower than in

\footnotetext{
${ }^{14}$ Results using GMM-DPD, which appear to yield rather sensible estimates, will not be reported further, since in many instances the hypothesis on the absence of second order autocorrelation and no overidentification are rejected.

${ }^{15}$ Percentage differences in TFP can be obtained as $\left[\exp \left(\delta_{\mathrm{j}}\right)-1\right]^{*} 100$, where $\delta_{\mathrm{j}}$ is the estimated coefficient associated to the international status dummy.
} 
the initial model, but these controls do not seem to explain much of the TFP premia of international firms. A more sizable drop in productivity premia is observed when we control for the skill composition (columns 3, 6, 9, 12). The share of managers and other white collars are strongly associated with firm TFP and, upon their inclusion, the TFP premia slide by more than $30 \%$ (column 5). This result highlights a possible misspecification in the production function. In particular, it suggests that the labor input should be split into different components capturing the different skill intensities. We will do this robustness check in section 5.3 and also provide evidence of complementarities between physical capital and high-skilled workers.

\subsection{Heterogeneity in the slope: evidence from a two-inputs production function}

Results presented in Table 7 support the idea that not all the heterogeneity among firms with different international engagement can be explained by differences in the constant of the production function. Even after controlling for a large number of firm characteristics, sizable differences in estimated TFP remain. In this section we will explore whether these differences can be explained by differences in the slopes of the production function, as illustrated in section 3. In particular, we estimate the production function for different sub-sample of firms, allowing different choices of the production technique for different firms. Based on the different estimated coefficients for capital and labor, we obtain TFP which accounts for heterogeneity in the slopes. We estimate different production functions for different sectors, and according to the size of the firm and the degree of international engagement ${ }^{16}$. Table 8 reports the coefficients on labor and capital for the different samples and using the four selected estimation method illustrated above (OLS-D, OP, LP, RE-AR1). Indeed, production function differs a lot across sectors, internationalization and size. For example, as one would expect, higher returns to scale are generally estimated for the Chemical and Pharmaceutical and the Printing and Publishing industries, while lower returns to scale are estimated in the Textile and Apparel industries. Interestingly, larger firms and multinational firms generally have higher returns to capital.

With these estimates at hand, we compute TFP as

\footnotetext{
${ }^{16}$ Unfortunately, the relatively low number of firms does not allow to further break down (and possibly interact) these categories.
} 
$T \hat{F} P_{i t}^{s}=\exp \left(y_{i t}-\hat{\beta}_{l}^{s} l_{i t}-\hat{\beta}_{k}^{s} k_{i t}\right)$

where $s=$ sector, size, internationalization

denotes whether the $\beta$ s have been obtained from sector, size or internationalizationspecific production functions.

In Table 9, A.1 and A.2 we replicate regressions of Table 7, using $T \hat{F} P_{i t}^{s}$ as the dependent variable. Table 9 reveals a rather striking result: once we allow for different production functions for multinational firms and exporters, their TFP premia vanishes (even without controlling for skill-intensity and the other firms' characteristics), and it turns out as they may have even lower TFP. This is particularly sizable for multinational firms, and consistent across estimation methods. This could be do to higher productivity of capital estimated for multinational firms and is consistent with Bloom, Sadun and Van Reenen (2007) who find that, once controlling for the higher productivity in the use of IT capital, multinational firms (and U.S. multinationals in particular) are not more productive than U.K national firms. For exporters, results are less robust, as the drop in TFP premium is smaller and in the case of OP estimation it goes in the opposite direction. Interestingly enough, this sharp change in the TFP premium is not obtained if we allow only sector-specific (Table A.1) or size-specific (Table A.2) production functions. This suggests that the result of Table 9 must have to do with the specific fact that international firms have different production functions, and not they are generally larger or concentrated in specific sectors.

Indeed, there is a number of reasons that point to a different production function for international firms. First, by organizing production across borders, multinational firms (and to some extent other internationalized firms, such as exporters, which may be also engaged in import of intermediates and outsourcing) use capital more intensively. Second, capital and labor may have different quality in international firms, which may require to make wider use of ICT to coordinate activities across-borders. Third, labor composition may differ and complementarities with the use of capital may emerge in international firms, if they are to implement better management practices.

\subsection{Heterogeneity in TFP and input complementarity: evidence from a four-inputs} production function 
In this section we will extend the analysis by allowing a more flexible specification of the production function, first identifying a separate effect for different types of labor inputs, such as the number of managers, clerks and other white collar workers, and production workers (blue collars) and then by allowing possible complementarities in the returns of inputs, using a translog specification. Table 10 reports the coefficients of the production function estimated with four types of inputs (capital and three types of labor inputs). Returns to scale are slightly lower in this case and this appears to be related to the fact that the model is less able to capture returns to the labor inputs. This may depend on some distortion, induced by the problems of the zeros in the labor input variables (e.g. small firms may have no managers). To avoid losing too many observations, we addressed this problem by taking the $\log (1+\mathrm{X})$, where $\mathrm{X}$ is the number of managers, white and blue collar workers. In Table 11 we report the coefficients of the production function estimated by international status. Results confirm that multinational firms have higher return to capital, while white collar workers appear relatively more productive in non-multinational exporters. Differences in the productivity of managers across firms type are less clear and slightly dependent on the estimation method.

Results on TFP premia for international firms, reported in Table 12, are broadly in line with evidence presented earlier: multinational firms and exporters have higher TFP when we estimate a production function common to all firms, but this premium turns negative if we account for differences in the slopes of the production function ${ }^{17}$.

As mentioned earlier, possible complementarities may emerge in the contribution of inputs to firm output. To investigate possible complementarities we estimate a translog production function for all firms and then we break it down by the degree of internationalization of firms ${ }^{18}$. To the best of our knowledge, the translog specification cannot be implemented in OP or LP methods, so we will estimate it only by OLS-D and RE-AR1. To fix ideas, our estimated equation is the following:

\footnotetext{
${ }^{17}$ For exporters the premium shrinks and it becomes non-significantly different from zero when estimated using OLS-D and OP. As shown earlier, when estimating internationalisation-specific production functions with OP, exporters exhibit a positive TFP premium.

${ }^{18}$ The translog production function does not impose any restrictions on the substitutability among inputs and provides a second-order local approximation to any twice-continuously differentiable production function (Diewert and Wales, 1987). Estimation of translog production functions is however more demanding in terms of identifying variance and tends to exacerbate bias due to measurement error (Epifani and Crinò, 2008).
} 


$$
y_{i t}=\sum_{r \in V} \beta_{x}^{s} \cdot r_{i t}+\frac{1}{2} \sum_{r \in V} \sum_{z \in V} \gamma_{r z}^{s} \cdot r_{i t} \cdot z_{i t}+u_{i t}
$$

where the input set $V=\{k, m, w, b\}$ includes the $\log$ capital $(k)$, managers $(m)$, other white collar $(w)$, production/blue collar $(b)$, and $\mathrm{s}=$ all firms, non-internationalized, exporters, multinationals.

The output elasticity of input $r$, becomes

$$
\lambda_{r, i t} \frac{\partial y_{i t}}{\partial r_{i t}}=\beta_{r}^{s}+\sum_{z \in V} \gamma_{r z}^{s} \cdot z_{i t}
$$

Results reported in Table 13 support the idea that positive complementarity between using managers and physical capital (positive interaction between $k$ and $m$ ) exists: firms' productivity would increase if they use both more capital and managers or, in other words, firms would benefit more from investing in physical capital, if they increase their managerial intensity. Interestingly enough, this complementarity is stronger for multinational firms and exporters. Conversely, and somewhat surprisingly, capital substitutes for white collars in all firms, but in multinationals the effect is stronger, and for production workers, especially in non-internationalized firms. Different types of workers tend to substitute for each other, the extent of this effect varies across types of firms: managers and white collars substitute rather strongly in exporters, managers substitute for production workers in internationalized firms and white collars, substitute for blue collars in exporters and non-internationalized firms.

\section{Concluding remarks}

Using data on a large sample of Italian manufacturing firms over the 1998-2003 period, we estimate the TFP premia of international firms. We confirm the rather established evidence that, even after controlling for sector, region and time effects, as well as other firms' characteristics (such as the innovative and investing behaviour, the legal status and the R\&D intensity), exporters achieve higher TFP than noninternational firms and multinational firms perform better than exporters. TFP premia for international firms shrink substantially once we account for the fact that these firms employ a higher share of knowledge workers, such as managers and clerks. These results are robust to various methods for estimating the production function. Instead, 
TFP premia for international firms vanish, if we account for the fact that the returns to capital and labour may differ. In fact, if we estimate different production functions for multinational firms, exporters and non-internationalised firms and recover TFP taking into account that the former have a substantially higher output elasticity returns of capital, international firms turn out to have even lower TFP than non-internationalised firms. This suggests that firm heterogeneity is in the slopes of the production function, and not only in the constant. A closer look at the production function of international firms, reveals also interesting complementarities between production factors. In particular, estimating a translog function, using a disaggregated definition of labour inputs, we find that managers and capital are complements in the productivity of multinational firms. This is consistent with the idea that multinational firms have superior organizational capabilities and managerial practices. 


\section{References}

Arnold, J. and K. Hussinger (2005) "Export versus FDI in German Manufacturing: Firm Performance and Participation in International Markets." Centre for European Economic Research Discussion Paper No. 05-73, October.

Barba Navaretti, G. and D. Castellani (2004) "Does investing abroad affect performance at home? Comparing Italian multinational and national enterprises", $C E P R$ Discussion Papers.

Black S.E. and L.M. Lynch (2001) "How to compete: The Impact of Workplace Practices and Information Technology on Productivity", The Review of Economics and Statistics, 83, 3, 434-445.

Black S.E. and L.M. Lynch (2004) "What's Driving the New Economy: The Benefits of Workplace Innovation", The Economic Journal, 114, F97-F116

Bloom N. and J. Van Reenen (2007) "Measuring and Explaining Management Practices Across Firms and Countries", Quarterly Journal of Economics, 122, 4, 1351-1408.

Bloom N., R. Sadun and J. Van Reenen (2007) "Americans Do I.T. Better: US Multinationals and the Productivity Miracle”, CEP Discussion Paper No 788.

Bresnahan T., E. Brynjolfsson and L.M. Hitt (2002) "Information Technology, Workplace Organization and the Demand for Skilled Labor: Firm-Level Evidence", Quarterly Journal of Economics, February 2002.

Brynjolfsson E. and L.M. Hitt (2003) "Computing Productivity: Firm-Level Evidence"; Review of Economic and Statistics, 85, 4, 793-808.

Castellani D. and A. Zanfei (2007) "Internationalisation, Productivity and Innovation: How Do Firms Differ in Italy?", The World Economy, 30, 1, 156-176, Jan 2007.

Criscuolo, C. and R. Martin (2003) "Multinationals, foreign ownership and US productivity leadership: evidence from the UK", mimeo.

De Backer, K. and L. Sleuwagen (2003) "Why are foreign firms more productive than domestic firms?", mimeo.

Doms, M. and B. Jensen (1998) "Comparing wages, skills, and productivity between domestically and foreign-owned manufacturing establishments in the United States", in Baldwin R., Lipsey R. and Richardson J.D. (eds) Geography and Ownership as Basis for Economic Accounting, University of Chicago Press.

Dunning, J.H. (1993) Multinational Enterprises and the Global Economy, Addison Wesley, Wokingham, England.

Girma, S., H. Gorg and E. Strobl (2004) "Exports, international investment and plant performance. Evidence from a non-parametric test", Economics Letters, forthcoming.

Girma, S., R. Kneller and M. Pisu (2003) "Exports versus FDI: An Empirical Test", Review of World Economics/Weltwirtschaftliches Archiv, 141, 2, pp.193-218.

Greenaway, D. and R. Kneller (2006) "Firm Heterogeneity, Exporting and Foreign Direct Investment: A Survey.” The Economic Journal, 116. 
Helpman, E., M. Meliz and S. Yeaple (2004) "Export versus FDI with Heterogenous Firms", American Economic Review, 94, 1, 300-316

Holmes T. , D. Levine and J. Schmitz (2008) "Monopoly and the Incentive to innovate when adoption involves switchover disruptions", NBER WP 13864, March

ISGEP (2007) "Export and Productivity: Comparable Evidence from 14 Countries", Working Papers 0714, University of Urbino Carlo Bo.

Markusen J. (2002) "Multinational Firms and the Theory of International Trade", Cambridge: MIT Press, 2002.

Mayer T. and G.I.P. Ottaviano (2007) "The Happy Few: The Internationalisation of European Firms", Bruegel Blueprint Series, November 2007.

Pfaffermayer, M. and C. Bellak (2002) "Why foreign-owned are different: a conceptual framework and empirical evidence for Austria", in R. Jungnickel (ed.) Foreignowned firms: are they different?, Palgrave-Macmillan, Houndmills.

Schmitz J (2005) "What determines productivity? Lessons from the Dramatic Recovery of the US and Canadian Iron Ore Industries Following their Early 1980s Crisis" Journal of Political Economy, June.

Van Biesebroeck J. (2007a) "Robustness of productivity estimates", Journal of Industrial Economics, LV, 3.

Van Biesebroeck J. (2007b) 'Revisiting some Productivity Debates', Journal of Business and Economic Statistics,

Wagner J. (2007) "Exports and Productivity: A Survey of the Evidence from Firm-level Data", The World Economy, 30, 1, 60-82, Jan 2007. 
Table 1 - Sample size, by year

Note:

\begin{tabular}{ccccc} 
Year & $\begin{array}{c}\text { Non } \\
\text { internationalised }\end{array}$ & $\begin{array}{c}\text { Non-multinational } \\
\text { exporters }\end{array}$ & $\begin{array}{c}\text { Multinational } \\
\text { firms }\end{array}$ & Total \\
1998 & 538 & 1,103 & 113 & 1,754 \\
1999 & 550 & 1,130 & 114 & 1,794 \\
2000 & 552 & 1,138 & 115 & 1,805 \\
2001 & $952(611)$ & $2,492(1,210)$ & $389(125)$ & $3,833(1,946)$ \\
2002 & $957(601)$ & $2,598(1,197)$ & $408(120)$ & $3,963(1,918)$ \\
2003 & $889(546)$ & $2,393(1,077)$ & $363(110)$ & $3,645(1,733)$ \\
\hline Total & $4,438(3,398)$ & $10,854(6,855)$ & $1,502(697)$ & $16,794(10,950)$ \\
& $26.4 \%(31.0 \%)$ & $64.6 \%(62.6 \%)$ & $8.9 \%(6.4 \%)$ & $100.0 \%$ \\
\hline
\end{tabular}

Missing and "anomalous" values in output (value added) and inputs (number of employees, number of managers, clerks and production workers) are excluded. Values of output and inputs are considered "anomalous" when a firmyear value is more than three times or less than one-third the median value for each firm. The table reports the number of observations for which all information needed to calculate TFP is available after cleaning.

The sample include observations from all firms surveyed in the $9^{\text {th }}$ Capitalia Survey (2001-2003). For about $60 \%$ of these firms we were able to gather information also from the in $8^{\text {th }}$ Capitalia Survey (1998-2000). In brackets we report the number of observations for 2001-2003 in the sample of firms which are in both surveys

Table 3 - Characteristics of the sample firms, by international status

\begin{tabular}{|c|c|c|c|c|}
\hline & $\begin{array}{c}\text { Non } \\
\text { internationalised }\end{array}$ & $\begin{array}{l}\text { Non-multinational } \\
\text { exporters }\end{array}$ & $\begin{array}{l}\text { Multinational } \\
\text { firms }\end{array}$ & Total \\
\hline & mean $\quad s d$ & mean $\quad s d$ & mean $\quad s d$ & mean $\quad$ sd \\
\hline Value added per worker & $45,960(27,894)$ & $50,022(30,386)$ & $64,436(48,530)$ & $50,238(32,182)$ \\
\hline Capital per worker & $49,128(72,078)$ & $42,651(52,663)$ & $55,809(78,735)$ & $45,539(61,134)$ \\
\hline N. employees & $49.6(104.5)$ & $105.9(328.7)$ & $391.4(659.6)$ & $116.5(345.8)$ \\
\hline \multicolumn{5}{|l|}{ Share of firms } \\
\hline Ltd. & $20.8 \%$ & $41.5 \%$ & $76.5 \%$ & $39.2 \%$ \\
\hline Innovating products & $19.2 \%$ & $41.1 \%$ & $52.3 \%$ & $36.3 \%$ \\
\hline Innovating processes & $35.7 \%$ & $42.1 \%$ & $52.0 \%$ & $41.3 \%$ \\
\hline Innovating organization & $17.6 \%$ & $26.9 \%$ & $39.7 \%$ & $25.6 \%$ \\
\hline Investing in mach. and eq. & $85.0 \%$ & $89.2 \%$ & $94.3 \%$ & $88.5 \%$ \\
\hline Investing in ICT & $63.0 \%$ & $73.4 \%$ & $86.5 \%$ & $71.8 \%$ \\
\hline \multicolumn{5}{|l|}{ Share of workers } \\
\hline Employed in R\&D & $1.9 \%$ & $3.8 \%$ & $3.9 \%$ & $3.3 \%$ \\
\hline Employed as managers & $2.8 \%$ & $3.7 \%$ & $4.7 \%$ & $3.6 \%$ \\
\hline Employed as clerks & $20.2 \%$ & $24.5 \%$ & $31.2 \%$ & $24.0 \%$ \\
\hline Employed in production & $69.0 \%$ & $66.4 \%$ & $62.4 \%$ & $66.8 \%$ \\
\hline
\end{tabular}


Figure 1 - Coefficients of the Cobb-Douglas production function, estimated using various methods

Coefficients of the Cobb-Douglas production function

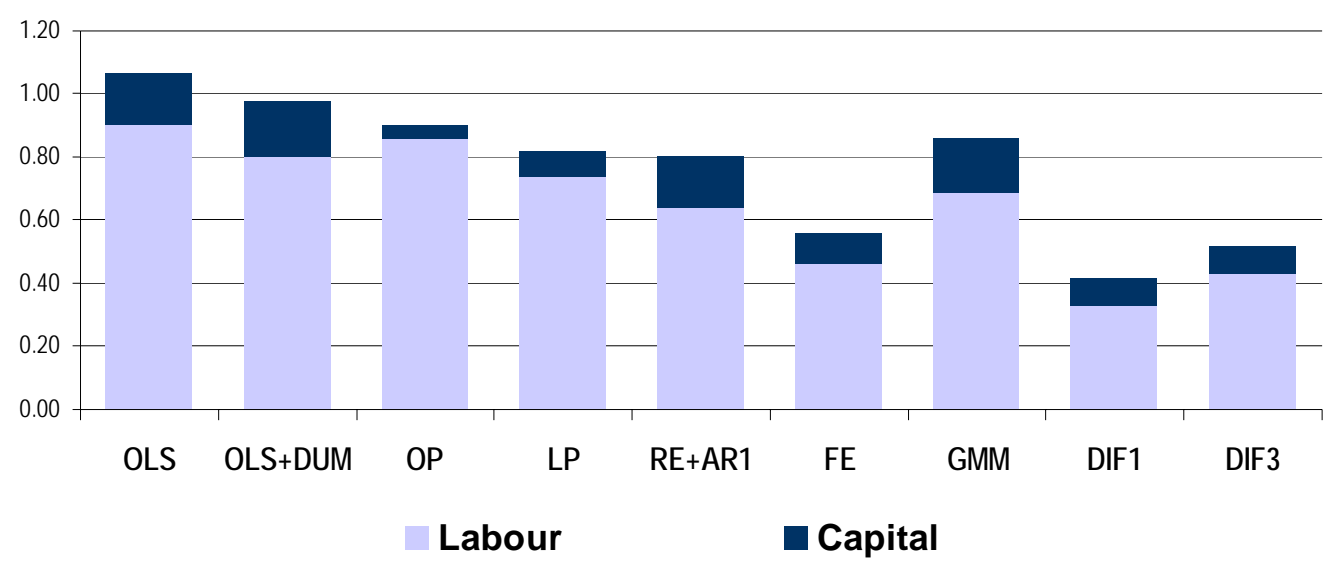

Table 4 - Estimated Coefficients of the production function

\begin{tabular}{lcc|cc|c}
\hline & \multicolumn{2}{c|}{ Labor } & \multicolumn{2}{c|}{ Capital } & RTS \\
& Coeff. & Std. Err. & Coeff. & Std. Err. & \\
\hline OLS & 0.899 & $(0.005)$ & 0.165 & $(0.003)$ & 1.065 \\
OLS+DUM & 0.799 & $(0.010)$ & 0.179 & $(0.003)$ & 0.978 \\
OP & 0.860 & $(0.009)$ & 0.041 & $(0.019)$ & 0.900 \\
LP & 0.736 & $(0.015)$ & 0.079 & $(0.014)$ & 0.816 \\
RE+AR1 & 0.638 & $(0.013)$ & 0.164 & $(0.004)$ & 0.802 \\
FE & 0.461 & $(0.016)$ & 0.099 & $(0.006)$ & 0.560 \\
GMM & 0.688 & $(0.141)$ & 0.171 & $(0.066)$ & 0.859 \\
DIF1 & 0.329 & $(0.021)$ & 0.087 & $(0.007)$ & 0.416 \\
DIF3 & 0.428 & $(0.021)$ & 0.089 & $(0.009)$ & 0.517 \\
\hline
\end{tabular}


Table 5 - Descriptives statistics of TFP calculated with different methods

\begin{tabular}{lcccccc}
\hline Variable & $\mathrm{N}$ & mean & sd & $\mathrm{p} 10$ & $\mathrm{p50}$ & $\mathrm{p} 90$ \\
\hline OLS & 16815 & 8.73 & 0.45 & 8.24 & 8.72 & 9.24 \\
OLS_D & 16815 & 8.93 & 0.46 & 8.42 & 8.93 & 9.47 \\
OP & 16815 & 10.63 & 0.52 & 10.04 & 10.62 & 11.24 \\
LP & 16815 & 10.57 & 0.55 & 9.95 & 10.54 & 11.24 \\
RE+AR1 & 16815 & 9.77 & 0.54 & 9.16 & 9.74 & 10.43 \\
FE & 16815 & 11.37 & 0.73 & 10.55 & 11.30 & 12.31 \\
GMM & 16815 & 9.47 & 0.51 & 8.90 & 9.45 & 10.08 \\
DIF1 & 16815 & 12.06 & 0.87 & 11.11 & 11.94 & 13.19 \\
DIF3 & 16815 & 11.64 & 0.77 & 10.78 & 11.55 & 12.64 \\
\hline
\end{tabular}

Table 6 - Correlation of TFP measures

$\mathrm{RE}+$

OLS OLS_D OP LP AR1 1 FE GMM DIF1 DIF3

\begin{tabular}{|c|c|c|c|c|c|c|c|c|c|}
\hline OLS & 1.00 & & & & & & & & \\
\hline OLS_D & 0.98 & 1.00 & & & & & & & \\
\hline $\mathrm{OP}$ & 0.87 & 0.92 & 1.00 & & & & & & \\
\hline LP & 0.82 & 0.91 & 0.99 & 1.00 & & & & & \\
\hline $\mathrm{RE}+\mathrm{AR} 1$ & 0.83 & 0.93 & 0.95 & 0.98 & 1.00 & & & & \\
\hline FE & 0.61 & 0.76 & 0.88 & 0.95 & 0.94 & 1.00 & & & \\
\hline GMM & 0.89 & 0.96 & 0.96 & 0.97 & 0.99 & 0.90 & 1.00 & & \\
\hline DIF1 & 0.52 & 0.68 & 0.83 & 0.91 & 0.90 & 0.99 & 0.85 & 1.00 & \\
\hline DIF3 & 0.58 & 0.73 & 0.87 & 0.94 & 0.93 & 1.00 & 0.88 & 1.00 & 1.00 \\
\hline
\end{tabular}


Table 7 - Productivity premia: dependent variable TFP

\begin{tabular}{|c|c|c|c|c|c|c|c|c|c|c|c|c|}
\hline & OLS_D & OLS_D & OLS_D & OP & OP & OP & LP & LP & LP & RE-AR1 & RE-AR1 & RE-AR1 \\
\hline \multirow[t]{2}{*}{ MNF } & $0.149 * \star \star$ & $0.123^{\star \star \star}$ & $0.072^{\star * \star}$ & $0.210 * \star *$ & $0.161^{* \star \star}$ & $0.112^{\star \star \star}$ & $0.202^{\star \star \star}$ & 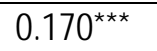 & $0.121^{* \star *}$ & $0.190 * \star \star$ & 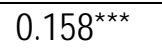 & $0.108^{\star \star \star}$ \\
\hline & $(0.026)$ & $(0.026)$ & $(0.025)$ & $(0.028)$ & $(0.028)$ & $(0.026)$ & $(0.028)$ & $(0.028)$ & $(0.026)$ & $(0.027)$ & $(0.027)$ & $(0.026)$ \\
\hline \multirow[t]{2}{*}{ Exporter } & $0.063^{\star \star *}$ & $0.053^{\star \star *}$ & $0.034^{* *}$ & $0.076^{\star \star *}$ & $0.057^{* * *}$ & $0.037^{* \star}$ & $0.073^{\star \star \star}$ & 0.060 *** & $0.041^{* \star *}$ & $0.074^{* \star *}$ & $0.061^{* \star *}$ & $0.042^{\star \star *}$ \\
\hline & $(0.015)$ & $(0.015)$ & $(0.014)$ & $(0.016)$ & $(0.016)$ & $(0.015)$ & $(0.016)$ & $(0.015)$ & $(0.014)$ & $(0.015)$ & $(0.015)$ & $(0.014)$ \\
\hline \multirow[t]{2}{*}{ Ltd. company } & & $0.112^{\star \star \star}$ & $0.078^{\star \star *}$ & & $0.172^{\star \star \star}$ & $0.139 * \star \star$ & & $0.168^{\star \star \star}$ & $0.135^{\star \star \star}$ & $9.152^{\star \star \star}$ & $0.137^{\star \star \star}$ & $0.104^{\star * *}$ \\
\hline & & $(0.015)$ & $(0.014)$ & & $(0.016)$ & $(0.015)$ & & $(0.015)$ & $(0.014)$ & $(0.065)$ & $(0.015)$ & $(0.014)$ \\
\hline \multirow[t]{2}{*}{ Product inno } & & $-0.042^{\star \star *}$ & $-0.040 * \star \star$ & & $-0.044^{\star \star \star}$ & $-0.042^{\star \star \star}$ & & $-0.041^{\star \star \star}$ & $-0.040^{\star \star *}$ & & $-0.039 * \star \star$ & $-0.037^{\star \star \star}$ \\
\hline & & $(0.013)$ & $(0.012)$ & & $(0.013)$ & $(0.013)$ & & $(0.013)$ & $(0.013)$ & & $(0.013)$ & $(0.012)$ \\
\hline \multirow[t]{2}{*}{ Process inno } & & -0.009 & 0.001 & & 0.005 & 0.015 & & 0.003 & 0.013 & & -0.004 & 0.006 \\
\hline & & $(0.012)$ & $(0.011)$ & & $(0.012)$ & $(0.012)$ & & $(0.012)$ & $(0.012)$ & & $(0.012)$ & $(0.011)$ \\
\hline \multirow[t]{2}{*}{ Organiz. inno } & & -0.005 & -0.013 & & -0.003 & -0.011 & & -0.003 & -0.011 & & -0.003 & -0.011 \\
\hline & & $(0.014)$ & $(0.013)$ & & $(0.015)$ & $(0.014)$ & & $(0.014)$ & $(0.014)$ & & $(0.014)$ & $(0.013)$ \\
\hline \multirow[t]{2}{*}{ Invest. in mach. } & & -0.007 & 0.011 & & 0.034 & 0.050 ** & & 0.022 & $0.039 *$ & & -0.003 & 0.014 \\
\hline & & $(0.022)$ & $(0.020)$ & & $(0.022)$ & $(0.021)$ & & $(0.022)$ & $(0.021)$ & & $(0.022)$ & $(0.020)$ \\
\hline \multirow[t]{2}{*}{ Invest. in info } & & 0.011 & -0.007 & & 0.003 & -0.014 & & 0.008 & -0.009 & & 0.014 & -0.003 \\
\hline & & $(0.014)$ & $(0.013)$ & & $(0.015)$ & $(0.014)$ & & $(0.014)$ & $(0.014)$ & & $(0.014)$ & $(0.013)$ \\
\hline \multicolumn{13}{|l|}{ Sh. of $R \& D$} \\
\hline \multirow[t]{2}{*}{ workers } & & $0.342^{\star \star \star}$ & -0.006 & & $0.281^{\star \star *}$ & -0.053 & & $0.259 * \star \star$ & -0.075 & & $0.274^{\star \star *}$ & -0.065 \\
\hline & & $(0.080)$ & $(0.079)$ & & $(0.080)$ & $(0.080)$ & & $(0.078)$ & $(0.079)$ & & $(0.079)$ & $(0.078)$ \\
\hline \multirow[t]{2}{*}{ Sh. of mgrs } & & & $0.902^{\star \star *}$ & & & $1.001^{* \star *}$ & & & $0.978^{\star \star *}$ & & $9.152^{\star \star \star}$ & 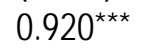 \\
\hline & & & $(0.124)$ & & & $(0.123)$ & & & $(0.122)$ & & $(0.067)$ & $(0.123)$ \\
\hline \multirow[t]{2}{*}{ Sh. of clerks } & & & $0.788^{* \star *}$ & & & $0.739 * \star \star$ & & & $0.740 * \star \star *$ & & & $0.762^{\star \star \star}$ \\
\hline & & & $(0.043)$ & & & $(0.045)$ & & & $(0.044)$ & & & $(0.043)$ \\
\hline \multirow[t]{2}{*}{ Constant } & $8.510 * \star *$ & $8.516^{* \star *}$ & $8.367^{\star \star *}$ & $10.024^{\star \star \star}$ & $10.178^{\star \star *}$ & $10.033^{* * *}$ & $10.205^{\star \star *}$ & $10.005^{\star \star \star}$ & $9.861^{\star \star *}$ & & & $9.006^{\star \star *}$ \\
\hline & $(0.065)$ & $(0.067)$ & $(0.065)$ & $(0.068)$ & $(0.072)$ & $(0.070)$ & $(0.070)$ & $(0.070)$ & $(0.068)$ & & & $(0.065)$ \\
\hline R2_a & .153 & .165 & .241 & .359 & .279 & .336 & .259 & .376 & .426 & .362 & .373 & .427 \\
\hline $\mathrm{N}^{-}$ & 16779 & 16758 & 16752 & 16779 & 16758 & 16752 & 16779 & 16758 & 16752 & 16779 & 16758 & 16752 \\
\hline N_clust & 4131 & 4131 & 4131 & 4131 & 4131 & 4131 & 4131 & 4131 & 4131 & 4131 & 4131 & 4131 \\
\hline
\end{tabular}


Table 8 - Parameters of the production function obtained with different methods and samples

\begin{tabular}{|c|c|c|c|c|c|c|c|c|c|c|c|c|}
\hline & \multicolumn{3}{|c|}{ OLS D } & \multicolumn{3}{|c|}{ OP } & \multicolumn{3}{|c|}{ RE-AR1 } & \multicolumn{3}{|c|}{ LP } \\
\hline & $\mathbf{L}$ & $\mathrm{K}$ & RTS & $\mathbf{L}$ & $\mathrm{K}$ & RTS & $\mathbf{L}$ & $\mathrm{K}$ & RTS & $\mathbf{L}$ & $\mathrm{K}$ & RTS \\
\hline All firms & 0.80 & 0.18 & 98 & 0.86 & 0.04 & 0.90 & 0.64 & 0.16 & 0.80 & 0.74 & 0.08 & 0.82 \\
\hline by international status & & & & & & & & & & & & \\
\hline Non international & 0.77 & 0.16 & 0.93 & 0.79 & 0.05 & 0.85 & 0.56 & 0.15 & 0.71 & 0.55 & 0.09 & 0.63 \\
\hline Exporters & 0.78 & 0.17 & 0.96 & 0.86 & 0.02 & 0.88 & 0.64 & 0.16 & 0.80 & 0.60 & 0.08 & 0.68 \\
\hline Multinationals & 0.76 & 0.23 & 0.99 & 0.78 & 0.15 & 0.93 & 0.71 & 0.21 & 0.92 & 0.59 & 0.10 & 0.69 \\
\hline by sector & & & & & & & & & & & & \\
\hline Food & 0.66 & 0.30 & 0.97 & 0.71 & 0.15 & 0.86 & 0.42 & 0.27 & 0.68 & 0.52 & 0.16 & 0.68 \\
\hline Textile & 0.75 & 0.15 & 0.91 & 0.79 & -0.18 & 0.61 & 0.69 & 0.11 & 0.80 & 0.64 & -0.04 & 0.60 \\
\hline Apparel & 0.67 & 0.19 & 0.86 & 0.85 & -0.15 & 0.70 & 0.72 & 0.13 & 0.85 & 0.74 & 0.04 & 0.78 \\
\hline Shoes & 0.87 & 0.15 & 1.02 & 0.83 & 0.17 & 1.01 & 0.73 & 0.13 & 0.86 & 0.70 & 0.14 & 0.84 \\
\hline $\begin{array}{l}\text { Wood and Paper } \\
\text { Printing and }\end{array}$ & 0.76 & 0.24 & 1.00 & 0.86 & 0.20 & 1.06 & 0.52 & 0.25 & 0.77 & 0.59 & 0.15 & 0.74 \\
\hline Publishing & 1.05 & 0.07 & 1.12 & 1.02 & 0.16 & 1.18 & 0.79 & 0.08 & 0.88 & 0.96 & 0.12 & 1.08 \\
\hline $\begin{array}{l}\text { Oil and Rubber } \\
\text { Chemical and }\end{array}$ & 0.71 & 0.32 & 1.02 & 0.76 & 0.09 & 0.85 & 0.54 & 0.28 & 0.82 & 0.61 & 0.13 & 0.74 \\
\hline Pharma & 1.01 & 0.13 & 1.13 & 1.00 & -0.02 & 0.98 & 0.80 & 0.13 & 0.93 & 0.77 & 0.00 & 0.76 \\
\hline Non-metallic minerals & 0.80 & 0.22 & 1.03 & 0.73 & 0.13 & 0.86 & 0.65 & 0.20 & 0.86 & 0.68 & 0.20 & 0.89 \\
\hline Metal & 0.99 & 0.13 & 1.12 & 0.82 & 0.03 & 0.85 & 0.87 & 0.10 & 0.96 & 0.77 & -0.06 & 0.71 \\
\hline Metalworking & 0.91 & 0.16 & & 0.84 & 0.10 & 0.94 & 0.73 & 0.15 & 0.88 & 0.76 & 0.13 & 0.88 \\
\hline Machinery & 0.89 & 0.10 & & 0.96 & 0.04 & 1.00 & 0.72 & 0.12 & 0.85 & 0.78 & 0.07 & 0.85 \\
\hline Electrical M & 0.78 & 0.09 & 0.8 & 92 & 0.06 & 0.98 & 0.60 & 0.11 & 0.70 & 0.82 & 0.13 & 0.96 \\
\hline & 0.65 & 0.18 & 0.8 & 0.91 & 0.00 & 0.91 & 0.62 & 0.18 & 0.80 & 0.64 & 0.11 & 0.76 \\
\hline Furnitures & 0.89 & 0.10 & & & 0.03 & & 0.71 & 0.11 & 0.82 & 0.66 & 0.08 & 0.74 \\
\hline Other & 0.97 & 0.12 & & 0.87 & 0.04 & 0.91 & 0.69 & 0.13 & 0.82 & 0.81 & 0.00 & 0.81 \\
\hline & & & & & & & & & & & & \\
\hline 20 or less & & & & & 0.01 & 0.5 & 0.41 & 0.11 & 0.52 & 0.55 & 0.07 & 0.62 \\
\hline $21-50$ & 0.86 & 0.16 & 1. & 0.86 & 0.00 & $0 . \varepsilon$ & 0.63 & 0.14 & 0.77 & 0.80 & 0.06 & 0.87 \\
\hline $51-250$ & 0.82 & 0.20 & 1. & 0.87 & 0.09 & 0.96 & 0.79 & 0.16 & 0.95 & 0.72 & 0.09 & 0.81 \\
\hline $251-499$ & 0.54 & 0.31 & 0.8 & 0.61 & 0.17 & 0.7 & 0.46 & 0.28 & 0.74 & 0.51 & 0.27 & 0.78 \\
\hline 500 or more & 0.45 & 0.50 & 0.96 & 0.61 & 0.25 & 0.86 & 0.40 & 0.46 & 0.86 & 0.53 & 0.23 & 0.76 \\
\hline
\end{tabular}


Table 9 - Productivity premia with intl. Specific production function

\begin{tabular}{|c|c|c|c|c|c|c|c|c|c|c|c|c|}
\hline & OLS_D & OLS_D & OLS_D & OP & OP & OP & LP & LP & LP & RE-AR1 & RE-AR1 & RE-AR1 \\
\hline \multirow[t]{2}{*}{ MNF } & $-0.762^{\star \star \star *}$ & $-0.788^{* \star \star}$ & $-0.840 * \star \star *$ & $-1.233^{\star \star \star}$ & $-1.274^{\star \star \star}$ & $-1.323^{\star \star \star}$ & $-0.173^{\star \star \star}$ & $-0.216^{\star \star \star}$ & $-0.265^{\star \star \star}$ & $-1.373^{* \star *}$ & $-1.404^{\star \star \star}$ & $-1.455^{\star \star \star}$ \\
\hline & $(0.026)$ & $(0.026)$ & $(0.025)$ & $(0.027)$ & $(0.027)$ & $(0.026)$ & $(0.029)$ & $(0.029)$ & $(0.027)$ & $(0.027)$ & $(0.027)$ & $(0.026)$ \\
\hline \multirow[t]{2}{*}{ Exporter } & $-0.135^{\star \star \star}$ & $-0.145^{\star \star \star}$ & $-0.165^{\star \star *}$ & $0.265^{\star \star \star}$ & $0.248 * \star *$ & $0.229 * \star \star$ & -0.020 & -0.036 ** & $-0.056^{\star \star *}$ & $-0.247^{\star \star *}$ & $-0.259 * \star *$ & $-0.279 * * *$ \\
\hline & $(0.015)$ & $(0.015)$ & $(0.014)$ & $(0.016)$ & $(0.016)$ & $(0.015)$ & $(0.016)$ & $(0.016)$ & $(0.015)$ & $(0.016)$ & $(0.015)$ & $(0.015)$ \\
\hline \multirow[t]{2}{*}{ Ltd. company } & & $0.115^{\star \star \star}$ & $0.081^{* * *}$ & & $0.175^{\star \star \star}$ & $0.142^{\star \star \star}$ & $10.483^{\star * \star}$ & $0.181^{\star \star \star}$ & $0.148^{* \star *}$ & & $0.137^{\star \star \star}$ & $0.104^{\star \star *}$ \\
\hline & & $(0.015)$ & $(0.014)$ & & $(0.016)$ & $(0.015)$ & $(0.068)$ & $(0.016)$ & $(0.015)$ & & $(0.015)$ & $(0.014)$ \\
\hline \multirow[t]{2}{*}{ Product inno } & & $-0.043^{* * *}$ & $-0.041^{\star \star *}$ & & $-0.046^{\star \star *}$ & $-0.045^{\star * *}$ & & $-0.040 * * *$ & $-0.039 * * *$ & & $-0.043^{\star \star *}$ & $-0.042^{\star \star \star}$ \\
\hline & & $(0.013)$ & $(0.012)$ & & $(0.014)$ & $(0.013)$ & & $(0.014)$ & $(0.013)$ & & $(0.013)$ & $(0.012)$ \\
\hline \multirow[t]{2}{*}{ Process inno } & & -0.007 & 0.003 & & 0.006 & 0.015 & & 0.005 & 0.014 & & -0.004 & 0.006 \\
\hline & & $(0.012)$ & (0.011) & & $(0.012)$ & $(0.012)$ & & $(0.012)$ & $(0.012)$ & & (0.012) & $(0.011)$ \\
\hline \multirow[t]{2}{*}{ Organiz. inno } & & -0.004 & -0.012 & & -0.000 & -0.008 & & -0.000 & -0.008 & & 0.001 & -0.007 \\
\hline & & $(0.014)$ & $(0.013)$ & & $(0.015)$ & $(0.014)$ & & $(0.015)$ & $(0.014)$ & & $(0.014)$ & $(0.013)$ \\
\hline \multirow[t]{2}{*}{ Invest. in mach. } & & -0.006 & 0.011 & & 0.034 & 0.050 ** & & 0.021 & $0.037^{*}$ & & -0.003 & 0.014 \\
\hline & & $(0.022)$ & $(0.020)$ & & $(0.022)$ & $(0.021)$ & & $(0.022)$ & $(0.021)$ & & $(0.022)$ & $(0.021)$ \\
\hline \multirow[t]{2}{*}{ Invest. in info } & & 0.010 & -0.008 & & 0.003 & -0.014 & & 0.012 & -0.005 & & 0.012 & -0.006 \\
\hline & & $(0.014)$ & $(0.013)$ & & $(0.015)$ & $(0.014)$ & & $(0.015)$ & $(0.014)$ & & $(0.014)$ & $(0.013)$ \\
\hline \multirow[t]{2}{*}{ Sh. of R\&D workers } & & $0.340 * * *$ & -0.009 & & 0.280 *** & -0.055 & & $0.208 * * *$ & -0.122 & & $0.278 * \star *$ & -0.067 \\
\hline & & $(0.080)$ & $(0.079)$ & & $(0.081)$ & $(0.082)$ & & $(0.079)$ & $(0.080)$ & & $(0.079)$ & $(0.079)$ \\
\hline \multirow[t]{2}{*}{ Sh. of mgrs } & & & $0.907^{* \star *}$ & & & $0.999 * * *$ & & $10.463^{* * *}$ & $0.988 * * *$ & & & $0.944^{* * *}$ \\
\hline & & & $(0.124)$ & & & $(0.122)$ & & $(0.069)$ & $(0.123)$ & & & $(0.124)$ \\
\hline \multirow[t]{2}{*}{ Sh. of clerks } & & & $0.788^{* * *}$ & & & $0.741^{\star \star *}$ & & & $0.730 * * *$ & & & $0.774^{* \star *}$ \\
\hline & & & $(0.043)$ & & & $(0.045)$ & & & $(0.045)$ & & & $(0.044)$ \\
\hline \multirow[t]{2}{*}{ Constant } & $8.814^{\star \star \star}$ & $8.819 * \star \star$ & $8.670 * \star \star$ & $10.257^{\star \star \star *}$ & $10.230^{\star \star \star *}$ & $10.085^{\star \star *}$ & & & $10.320 * \star *$ & $9.555^{\star \star \star}$ & $9.557^{\star \star *}$ & $9.409 * * *$ \\
\hline & $(0.065)$ & $(0.067)$ & $(0.065)$ & $(0.070)$ & $(0.072)$ & $(0.070)$ & & & $(0.068)$ & $(0.065)$ & $(0.067)$ & $(0.065)$ \\
\hline R2_a & .216 & .227 & .298 & .48 & .495 & .534 & .465 & .48 & .52 & .423 & .433 & .483 \\
\hline N. obs. & 16779 & 16758 & 16752 & 16779 & 16758 & 16752 & 16779 & 16758 & 16752 & 16779 & 16758 & 16752 \\
\hline N. firms & 4131 & 4131 & 4131 & 4131 & 4131 & 4131 & 4131 & 4131 & 4131 & 4131 & 4131 & 4131 \\
\hline
\end{tabular}


Table 10 - Production function with four inputs: coefficients and TFP estimates

\begin{tabular}{lrrrr|r|rrr}
\hline & CAPITAL & MGRS & WHITE & BLUE & RTS & N & mean & Sd \\
\hline OLS & 0.189 & 0.159 & 0.445 & 0.287 & 1.081 & 16907 & 9.71 & 0.46 \\
OLS_D & 0.188 & 0.128 & 0.339 & 0.182 & 0.837 & 16907 & 10.36 & 0.53 \\
OP & 0.075 & 0.141 & 0.438 & 0.275 & 0.929 & 16907 & 11.57 & 0.64 \\
LP & 0.105 & 0.087 & 0.269 & 0.230 & 0.691 & 16907 & 11.39 & 0.51 \\
RE-AR1 & 0.182 & 0.078 & 0.224 & 0.129 & 0.613 & 16907 & 10.96 & 0.68 \\
FE & 0.110 & 0.007 & 0.078 & 0.149 & 0.344 & 16907 & 12.31 & 0.93 \\
GMM & 0.216 & -0.004 & 0.060 & 0.124 & 0.396 & 16907 & 10.96 & 0.86 \\
DIF1 & 0.091 & 0.003 & 0.049 & 0.095 & 0.239 & 16907 & 12.82 & 1.03 \\
DIF3 & 0.097 & 0.010 & 0.085 & 0.161 & 0.353 & 16907 & 12.43 & 0.93 \\
\hline
\end{tabular}

Table 11 - Coefficients production function with 4 inputs

\begin{tabular}{lrlll|l|}
\hline & CAPITAL MGRS & WHITE & BLUE & $R T S$ \\
\hline OLS_D & & & & & \\
Non-intl. & 0.165 & 0.136 & 0.296 & 0.188 & 0.785 \\
Exporter & 0.184 & 0.119 & 0.357 & 0.180 & 0.840 \\
Multinational & 0.263 & 0.120 & 0.271 & 0.205 & 0.859 \\
\hline OP & & & & & \\
Non-intl. & 0.072 & 0.165 & 0.373 & 0.284 & 0.893 \\
Exporter & 0.055 & 0.128 & 0.459 & 0.299 & 0.941 \\
Multinational & 0.219 & 0.133 & 0.380 & 0.130 & 0.862 \\
\hline LP & & & & & \\
Non-intl. & 0.096 & 0.084 & 0.228 & 0.239 & 0.648 \\
Exporter & 0.097 & 0.092 & 0.286 & 0.232 & 0.707 \\
Multinational & 0.133 & 0.070 & 0.234 & 0.216 & 0.654 \\
\hline RE & & & & & \\
Non-intl. & 0.156 & 0.067 & 0.202 & 0.122 & 0.547 \\
Exporter & 0.178 & 0.067 & 0.242 & 0.121 & 0.607 \\
Multinational & 0.249 & 0.128 & 0.161 & 0.175 & 0.714 \\
\hline
\end{tabular}


Table 12 - Productivity premia when TFP is calculated from a 4 inputs p.f.

\begin{tabular}{|c|c|c|c|c|c|c|c|c|c|c|c|c|c|c|c|c|}
\hline & \multicolumn{8}{|c|}{ One production function for all firms } & \multicolumn{8}{|c|}{ Heterogeneous production function (by internationalization) } \\
\hline & OLS_D & OLS_D & OP & OP & LP & LP & RE & RE & OLS_D & OLS_D & OP & OP & LP & LP & RE & RE \\
\hline \multirow[t]{2}{*}{ MNF } & 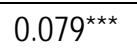 & $0.073^{\star \star \star}$ & $0.065^{\star \star}$ & $0.058^{\star \star}$ & $0.162^{\star \star \star}$ & $0.137^{\star \star *}$ & $\mathrm{~b} / \mathrm{se}$ & $0.144^{\star \star *}$ & $-1.288^{\star \star \star}$ & $-1.293^{\star \star \star}$ & $-1.408^{\star \star \star}$ & $-1.415^{\star \star \star}$ & $-0.216^{\star \star \star}$ & $-0.241^{\star \star \star}$ & $-1.372^{\star \star \star}$ & $-1.394^{\star \star \star}$ \\
\hline & $(0.027)$ & $(0.027)$ & $(0.029)$ & $(0.029)$ & $(0.029)$ & $(0.029)$ & $0.166^{\star \star \star}$ & $(0.029)$ & $(0.027)$ & $(0.027)$ & $(0.028)$ & $(0.028)$ & $(0.030)$ & $(0.030)$ & $(0.029)$ & $(0.029)$ \\
\hline \multirow[t]{2}{*}{ Exporter } & 0.021 & 0.022 & 0.009 & 0.008 & $0.046^{* \star *}$ & $0.037^{\star *}$ & $(0.029)$ & $0.044^{* * *}$ & $-0.317^{\star * *}$ & $-0.316^{\star \star *}$ & $0.037^{* *}$ & $0.036^{\star *}$ & $-0.060^{* * *}$ & $-0.068^{\star * *}$ & $-0.314^{\star * *}$ & $-0.321^{* * *}$ \\
\hline & $(0.015)$ & $(0.015)$ & $(0.015)$ & $(0.015)$ & $(0.015)$ & $(0.015)$ & $0.051^{* * *}$ & $(0.015)$ & $(0.015)$ & $(0.015)$ & $(0.015)$ & $(0.015)$ & $(0.016)$ & $(0.015)$ & $(0.016)$ & $(0.015)$ \\
\hline \multirow{2}{*}{ Ltd. company } & & $0.079 * \star *$ & & $0.102^{\star * *}$ & $10.903^{* \star *}$ & $0.144^{\star \star *}$ & $(0.015)$ & $0.125^{\star \star \star}$ & & $0.081^{\star \star *}$ & & $0.105^{\star \star \star}$ & $11.066^{\star \star *}$ & $0.145^{\star \star \star}$ & $10.546^{\star \star *}$ & $0.126^{\star \star \star}$ \\
\hline & & $(0.015)$ & & $(0.015)$ & $(0.061)$ & $(0.015)$ & $10.142^{\star \star *}$ & $(0.015)$ & & $(0.015)$ & & $(0.015)$ & $(0.061)$ & $(0.015)$ & $(0.060)$ & $(0.015)$ \\
\hline \multirow[t]{2}{*}{ Product inno } & & $-0.042^{* * *}$ & & -0.050 *** & & $-0.043^{\star \star \star}$ & $(0.060)$ & $-0.037^{\star \star *}$ & & $-0.046^{\star \star *}$ & & $-0.052^{\star \star *}$ & & $-0.045^{\star \star *}$ & & $-0.041^{* * *}$ \\
\hline & & $(0.013)$ & & $(0.014)$ & & $(0.014)$ & & $(0.014)$ & & $(0.013)$ & & $(0.014)$ & & $(0.014)$ & & $(0.014)$ \\
\hline \multirow[t]{2}{*}{ Process inno } & & -0.007 & & 0.001 & & -0.000 & & -0.003 & & -0.006 & & 0.002 & & -0.000 & & -0.001 \\
\hline & & $(0.012)$ & & $(0.013)$ & & $(0.012)$ & & $(0.012)$ & & $(0.012)$ & & $(0.013)$ & & $(0.012)$ & & $(0.012)$ \\
\hline \multirow[t]{2}{*}{ Organiz. inno } & & -0.015 & & -0.016 & & -0.008 & & -0.008 & & -0.013 & & -0.016 & & -0.007 & & -0.005 \\
\hline & & $(0.014)$ & & $(0.015)$ & & $(0.015)$ & & $(0.015)$ & & $(0.014)$ & & $(0.015)$ & & $(0.015)$ & & $(0.015)$ \\
\hline \multirow[t]{2}{*}{ Invest. in mach. } & & 0.017 & & $0.056^{\star * *}$ & & 0.032 & & 0.008 & & 0.017 & & $0.057^{\star * *}$ & & 0.034 & & 0.009 \\
\hline & & $(0.021)$ & & $(0.021)$ & & $(0.021)$ & & $(0.022)$ & & $(0.021)$ & & $(0.021)$ & & $(0.022)$ & & $(0.022)$ \\
\hline \multirow[t]{2}{*}{ Invest. in info } & & -0.015 & & $-0.034^{\star \star}$ & & -0.007 & & 0.002 & & -0.016 & & $-0.033^{\star *}$ & & -0.007 & & -0.001 \\
\hline & & $(0.014)$ & & $(0.015)$ & & $(0.015)$ & & $(0.015)$ & & $(0.014)$ & & $(0.015)$ & & $(0.015)$ & & $(0.015)$ \\
\hline \multirow[t]{2}{*}{ Sh. of R\&D workers } & & -0.032 & & -0.059 & & 0.047 & & 0.000 & & -0.022 & & -0.041 & & 0.043 & & 0.000 \\
\hline & & $(0.078)$ & & $(0.081)$ & & $(0.079)$ & & $(0.078)$ & & $(0.077)$ & & $(0.083)$ & & $(0.079)$ & & $(0.078)$ \\
\hline \multirow[t]{2}{*}{ Constant } & $9.817^{\star \star *}$ & $9.818^{\star * \star}$ & $11.044^{\star \star *}$ & $11.019 * * *$ & & $10.885^{\star \star *}$ & & $10.140^{* * *}$ & $10.185^{\star \star \star}$ & $10.185^{\star * *}$ & $11.170^{\star \star *}$ & $11.144^{\star \star \star}$ & & $11.046^{* * *}$ & & $10.544^{\star \star *}$ \\
\hline & $(0.058)$ & $(0.060)$ & $(0.060)$ & $(0.063)$ & & $(0.063)$ & & $(0.062)$ & $(0.058)$ & $(0.060)$ & $(0.061)$ & $(0.063)$ & & $(0.063)$ & & $(0.062)$ \\
\hline r2_a & .328 & .335 & .23 & .242 & .513 & .524 & .574 & .582 & .394 & .401 & .448 & .46 & .471 & .483 & .538 & .546 \\
\hline N. obs. & 16892 & 16881 & 16892 & 16881 & 16892 & 16881 & 16892 & 16881 & 16892 & 16881 & 16892 & 16881 & 16892 & 16881 & 16892 & 16881 \\
\hline N. firms & 4139 & 4139 & 4139 & 4139 & 4139 & 4139 & 4139 & 4139 & 4139 & 4139 & 4139 & 4139 & 4139 & 4139 & 4139 & 4139 \\
\hline
\end{tabular}


Table 13 - Translog production function

\begin{tabular}{|c|c|c|c|c|c|c|c|c|}
\hline $\begin{array}{l}\text { Sample } \\
\text { Method }\end{array}$ & $\begin{array}{l}\text { All firms } \\
\text { OLS-D }\end{array}$ & $\begin{array}{l}\text { Non-intl } \\
\text { OLS-D }\end{array}$ & $\begin{array}{l}\text { Exporters } \\
\text { OLS-D }\end{array}$ & $\begin{array}{l}\text { MNFs } \\
\text { OLS-D }\end{array}$ & \begin{tabular}{|l|} 
All firms \\
RE-AR1 \\
\end{tabular} & $\begin{array}{l}\text { Non-intl } \\
\text { RE-AR1 }\end{array}$ & $\begin{array}{l}\text { Exporters } \\
\text { RE-AR1 }\end{array}$ & $\begin{array}{l}\text { MNFs } \\
\text { RE-AR1 }\end{array}$ \\
\hline k & $\begin{array}{l}-0.360^{*} \\
(0.215)\end{array}$ & $\begin{array}{l}-0.878^{\star \star \star} \\
(0.129)\end{array}$ & $\begin{array}{l}-0.120 \\
(0.239)\end{array}$ & $\begin{array}{l}-1.000^{* *} \\
(0.447)\end{array}$ & $\begin{array}{l}-0.320^{\star \star \star} \\
(0.042)\end{array}$ & $\begin{array}{l}-0.606^{\star \star *} \\
(0.084)\end{array}$ & $\begin{array}{l}-0.190^{\star \star \star} \\
(0.053)\end{array}$ & $\begin{array}{l}-0.542^{\star \star \star} \\
(0.177)\end{array}$ \\
\hline$m$ & $\begin{array}{l}-0.175 \\
(0.184)\end{array}$ & $\begin{array}{l}0.096 \\
(0.158)\end{array}$ & $\begin{array}{l}-0.249 \\
(0.219)\end{array}$ & $\begin{array}{l}-0.622 \\
(0.496)\end{array}$ & $\begin{array}{l}-0.220^{\star \star \star} \\
(0.049)\end{array}$ & $\begin{array}{l}-0.017 \\
(0.106)\end{array}$ & $\begin{array}{l}-0.217^{\star \star *} \\
(0.060)\end{array}$ & $\begin{array}{l}-0.411^{\star \star} \\
(0.198)\end{array}$ \\
\hline$w$ & $\begin{array}{l}0.733^{\star \star \star} \\
(0.128)\end{array}$ & $\begin{array}{l}0.892^{\star \star \star} \\
(0.141)\end{array}$ & $\begin{array}{l}0.721^{\star \star \star} \\
(0.166)\end{array}$ & $\begin{array}{l}1.602^{\star \star *} \\
(0.395)\end{array}$ & $\begin{array}{l}0.397^{\star \star *} \\
(0.048)\end{array}$ & $\begin{array}{l}0.516^{\star \star \star} \\
(0.101)\end{array}$ & $\begin{array}{l}0.369^{* * *} \\
(0.064)\end{array}$ & $\begin{array}{l}0.964^{\star \star *} \\
(0.218)\end{array}$ \\
\hline$b$ & $\begin{array}{l}0.015 \\
(0.220)\end{array}$ & $\begin{array}{l}0.646^{\star * \star} \\
(0.132)\end{array}$ & $\begin{array}{l}-0.255 \\
(0.272)\end{array}$ & $\begin{array}{l}0.585 \\
(0.417)\end{array}$ & $\begin{array}{l}0.066 \\
(0.042)\end{array}$ & $\begin{array}{l}0.495^{\star * \star} \\
(0.081)\end{array}$ & $\begin{array}{l}-0.130^{* *} \\
(0.055)\end{array}$ & $\begin{array}{l}0.222 \\
(0.171)\end{array}$ \\
\hline$k^{2}$ & $\begin{array}{l}0.020^{*} \\
(0.011)\end{array}$ & $\begin{array}{l}0.047^{\star \star *} \\
(0.006)\end{array}$ & $\begin{array}{l}0.008 \\
(0.013)\end{array}$ & $\begin{array}{l}0.056^{\star \star \star} \\
(0.021)\end{array}$ & $\begin{array}{l}0.020^{\star * *} \\
(0.002)\end{array}$ & $\begin{array}{l}0.035^{* * *} \\
(0.004)\end{array}$ & $\begin{array}{l}0.013^{\star * *} \\
(0.002)\end{array}$ & $\begin{array}{l}0.034^{* \star *} \\
(0.008)\end{array}$ \\
\hline$m^{2}$ & $\begin{array}{l}-0.002 \\
(0.009)\end{array}$ & $\begin{array}{l}-0.020 \\
(0.015)\end{array}$ & $\begin{array}{l}0.019^{\star} \\
(0.011)\end{array}$ & $\begin{array}{l}-0.022 \\
(0.025)\end{array}$ & $\begin{array}{l}0.005 \\
(0.004)\end{array}$ & $\begin{array}{l}-0.008 \\
(0.013)\end{array}$ & $\begin{array}{l}0.013^{\star \star} \\
(0.006)\end{array}$ & $\begin{array}{l}-0.008 \\
(0.012)\end{array}$ \\
\hline$w^{2}$ & $\begin{array}{l}0.071^{* \star *} \\
(0.006)\end{array}$ & $\begin{array}{l}0.065^{\star \star \star} \\
(0.013)\end{array}$ & $\begin{array}{l}0.081^{\star \star \star} \\
(0.010)\end{array}$ & $\begin{array}{l}0.067^{\star \star \star} \\
(0.012)\end{array}$ & $\begin{array}{l}0.058^{\star \star \star} \\
(0.004)\end{array}$ & $\begin{array}{l}0.053^{\star \star \star} \\
(0.009)\end{array}$ & $\begin{array}{l}0.061^{* * *} \\
(0.006)\end{array}$ & $\begin{array}{l}0.068^{\star * \star} \\
(0.009)\end{array}$ \\
\hline$b^{2}$ & $\begin{array}{l}0.046^{\star \star \star} \\
(0.009)\end{array}$ & $\begin{array}{l}0.068^{\star \star \star} \\
(0.013)\end{array}$ & $\begin{array}{l}0.036^{\star \star *} \\
(0.012)\end{array}$ & $\begin{array}{l}0.066^{\star \star \star} \\
(0.015)\end{array}$ & $\begin{array}{l}0.045^{\star \star *} \\
(0.003)\end{array}$ & $\begin{array}{l}0.055^{\star \star \star} \\
(0.007)\end{array}$ & $\begin{array}{l}0.041^{* * *} \\
(0.004)\end{array}$ & $\begin{array}{l}0.062^{\star \star *} \\
(0.009)\end{array}$ \\
\hline$k^{\star} m$ & $\begin{array}{l}0.039^{* *} \\
(0.017)\end{array}$ & $\begin{array}{l}0.005 \\
(0.014)\end{array}$ & $\begin{array}{l}0.047^{\star *} \\
(0.021)\end{array}$ & $\begin{array}{l}0.072^{\star} \\
(0.043)\end{array}$ & $\begin{array}{l}0.034^{\star \star \star} \\
(0.004)\end{array}$ & $\begin{array}{l}0.010 \\
(0.009)\end{array}$ & $\begin{array}{l}0.035^{\star \star \star} \\
(0.005)\end{array}$ & $\begin{array}{l}0.061^{* \star *} \\
(0.016)\end{array}$ \\
\hline$k^{\star} W$ & $\begin{array}{l}-0.036^{\star \star \star} \\
(0.012)\end{array}$ & $\begin{array}{l}-0.051^{\star \star \star} \\
(0.012)\end{array}$ & $\begin{array}{l}-0.035^{\star *} \\
(0.016)\end{array}$ & $\begin{array}{l}-0.113^{\star \star \star} \\
(0.032)\end{array}$ & $\begin{array}{l}-0.024^{\star \star \star} \\
(0.004)\end{array}$ & $\begin{array}{l}-0.033^{\star \star \star} \\
(0.008)\end{array}$ & $\begin{array}{l}-0.022^{\star \star \star} \\
(0.005)\end{array}$ & $\begin{array}{l}-0.079^{\star \star *} \\
(0.017)\end{array}$ \\
\hline$k^{\star} b$ & $\begin{array}{l}0.014 \\
(0.021)\end{array}$ & $\begin{array}{l}-0.043^{\star \star \star} \\
(0.013)\end{array}$ & $\begin{array}{l}0.039 \\
(0.026)\end{array}$ & $\begin{array}{l}-0.041 \\
(0.036)\end{array}$ & $\begin{array}{l}-0.004 \\
(0.003)\end{array}$ & $\begin{array}{l}-0.040^{\star \star *} \\
(0.007)\end{array}$ & $\begin{array}{l}0.012^{\star \star *} \\
(0.004)\end{array}$ & $\begin{array}{l}-0.022^{\star} \\
(0.013)\end{array}$ \\
\hline$m^{\star} W$ & $\begin{array}{l}-0.018^{\star} \\
(0.010)\end{array}$ & $\begin{array}{l}0.010 \\
(0.018)\end{array}$ & $\begin{array}{l}-0.050^{\star \star \star} \\
(0.016)\end{array}$ & $\begin{array}{l}0.032 \\
(0.019)\end{array}$ & $\begin{array}{l}-0.015^{\star \star \star} \\
(0.005)\end{array}$ & $\begin{array}{l}-0.004 \\
(0.014)\end{array}$ & $\begin{array}{l}-0.023^{\star \star \star} \\
(0.008)\end{array}$ & $\begin{array}{l}0.013 \\
(0.014)\end{array}$ \\
\hline$m^{*} b$ & $\begin{array}{l}-0.067^{\star \star \star} \\
(0.017)\end{array}$ & $\begin{array}{l}-0.012 \\
(0.019)\end{array}$ & $\begin{array}{l}-0.069^{\star \star \star} \\
(0.022)\end{array}$ & $\begin{array}{l}-0.102^{\star \star \star} \\
(0.039)\end{array}$ & $\begin{array}{l}-0.051^{\star \star \star} \\
(0.005)\end{array}$ & $\begin{array}{l}-0.010 \\
(0.013)\end{array}$ & $\begin{array}{l}-0.055^{\star \star \star} \\
(0.007)\end{array}$ & $\begin{array}{l}-0.105^{* * *} \\
(0.018)\end{array}$ \\
\hline$w^{*} b$ & $\begin{array}{l}-0.064^{\star \star \star} \\
(0.013)\end{array}$ & $\begin{array}{l}-0.059^{\star \star \star} \\
(0.018)\end{array}$ & $\begin{array}{l}-0.070^{\star \star \star} \\
(0.020)\end{array}$ & $\begin{array}{l}-0.010 \\
(0.021)\end{array}$ & $\begin{array}{l}-0.029^{\star \star \star} \\
(0.005)\end{array}$ & $\begin{array}{l}-0.021^{\star *} \\
(0.009)\end{array}$ & $\begin{array}{l}-0.029^{\star \star \star} \\
(0.007)\end{array}$ & $\begin{array}{l}0.004 \\
(0.018)\end{array}$ \\
\hline _cons & $\begin{array}{l}13.318^{\star \star \star *} \\
(0.981)\end{array}$ & $\begin{array}{l}15.647^{\star \star \star} \\
(0.774)\end{array}$ & $\begin{array}{l}12.172^{\star \star \star} \\
(1.043)\end{array}$ & $\begin{array}{l}16.423^{* * \star} \\
(2.423)\end{array}$ & $\begin{array}{l}13.553^{\star \star \star} \\
(0.261) \\
\end{array}$ & $\begin{array}{l}14.645^{\star \star \star} \\
(0.520)\end{array}$ & $\begin{array}{l}13.072^{\star \star \star} \\
(0.336)\end{array}$ & $\begin{array}{l}14.263^{\star \star \star} \\
(1.122)\end{array}$ \\
\hline sector & yes & yes & yes & yes & yes & yes & yes & yes \\
\hline time & yes & yes & yes & yes & yes & yes & yes & yes \\
\hline sector*time & yes & yes & yes & yes & yes & yes & yes & yes \\
\hline size & yes & yes & yes & yes & yes & yes & yes & yes \\
\hline region & yes & yes & yes & yes & yes & yes & yes & yes \\
\hline r2_a & .903 & .844 & .885 & .927 & & & & \\
\hline $\begin{array}{l}\text { N. obs. } \\
\text { N. firms }\end{array}$ & $\begin{array}{l}16928 \\
4150\end{array}$ & $\begin{array}{l}4460 \\
1012\end{array}$ & $\begin{array}{l}10931 \\
2704\end{array}$ & $\begin{array}{l}1516 \\
429\end{array}$ & $\begin{array}{l}16928 \\
4150\end{array}$ & $\begin{array}{l}4460 \\
1012\end{array}$ & $\begin{array}{l}10931 \\
2704\end{array}$ & $\begin{array}{l}1516 \\
429\end{array}$ \\
\hline
\end{tabular}


Table A.1 - Productivity premia with sector-specific production function

\begin{tabular}{|c|c|c|c|c|c|c|c|c|c|c|c|c|}
\hline & OLS_D & OLS_D & OLS_D & OP & $\mathrm{OP}$ & OP & LP & LP & LP & RE-AR1 & RE-AR1 & RE-AR1 \\
\hline \multirow[t]{2}{*}{ MNF } & $0.127^{\star \star \star}$ & $0.100 * \star *$ & $0.055^{\star \star}$ & $0.178^{\star \star \star}$ & $0.138^{\star * *}$ & $0.093^{\star \star \star}$ & $0.195^{\star \star \star}$ & $0.156^{\star \star \star}$ & $0.111^{\star * \star}$ & $0.174^{\star \star \star}$ & $0.142^{\star \star \star}$ & $0.097^{\star \star \star}$ \\
\hline & $(0.026)$ & $(0.026)$ & $(0.025)$ & $(0.029)$ & $(0.029)$ & $(0.028)$ & $(0.028)$ & $(0.028)$ & $(0.027)$ & $(0.027)$ & $(0.027)$ & $(0.026)$ \\
\hline \multirow[t]{2}{*}{ Exporter } & $0.053^{\star \star *}$ & $0.041 * * *$ & $0.024^{*}$ & $0.055^{\star \star \star}$ & $0.038^{\star *}$ & 0.021 & $0.064^{\star \star \star}$ & $0.048^{* * *}$ & $0.031^{\star *}$ & $0.065^{\star \star \star}$ & $0.052^{\star \star \star}$ & $0.034^{\star \star}$ \\
\hline & $(0.015)$ & $(0.015)$ & $(0.014)$ & $(0.017)$ & $(0.016)$ & $(0.016)$ & $(0.016)$ & $(0.016)$ & $(0.015)$ & $(0.015)$ & $(0.015)$ & $(0.014)$ \\
\hline \multirow[t]{2}{*}{ Ltd. company } & & $0.119 * \star \star$ & $0.089 * \star \star$ & & 0.159 *** & $0.129 * \star \star$ & & $0.159 * \star \star$ & $0.129 * \star \star$ & & $0.134^{\star \star \star}$ & $0.103^{\star \star \star}$ \\
\hline & & $(0.015)$ & $(0.014)$ & & $(0.016)$ & $(0.015)$ & & $(0.015)$ & $(0.015)$ & & $(0.015)$ & $(0.014)$ \\
\hline \multirow[t]{2}{*}{ Product inno } & & $-0.031^{\star *}$ & $-0.030^{\star \star}$ & & $-0.029 \star \star$ & $-0.028 * *$ & & $-0.037^{\star \star \star}$ & $-0.035^{\star \star \star}$ & & $-0.031^{\star *}$ & -0.030 ** \\
\hline & & $(0.013)$ & $(0.012)$ & & $(0.014)$ & $(0.014)$ & & $(0.014)$ & $(0.013)$ & & $(0.013)$ & $(0.013)$ \\
\hline \multirow[t]{2}{*}{ Process inno } & & -0.010 & -0.001 & & 0.005 & 0.014 & & 0.003 & 0.012 & & -0.006 & 0.003 \\
\hline & & $(0.012)$ & $(0.011)$ & & $(0.013)$ & $(0.012)$ & & $(0.012)$ & $(0.012)$ & & $(0.012)$ & $(0.011)$ \\
\hline \multirow[t]{2}{*}{ Organiz. inno } & & -0.004 & -0.011 & & -0.005 & -0.013 & & -0.002 & -0.009 & & 0.002 & -0.006 \\
\hline & & $(0.014)$ & $(0.013)$ & & $(0.015)$ & $(0.015)$ & & $(0.015)$ & $(0.014)$ & & $(0.014)$ & $(0.013)$ \\
\hline \multirow[t]{2}{*}{ Invest. in mach. } & & 0.005 & 0.020 & & $0.039^{*}$ & $0.054^{\star \star}$ & & 0.020 & $0.035^{\star}$ & & 0.002 & 0.017 \\
\hline & & $(0.021)$ & $(0.020)$ & & $(0.023)$ & $(0.022)$ & & $(0.022)$ & $(0.021)$ & & $(0.021)$ & $(0.020)$ \\
\hline \multirow[t]{2}{*}{ Invest. in info } & & 0.002 & -0.014 & & -0.001 & -0.016 & & 0.008 & -0.008 & & 0.007 & -0.009 \\
\hline & & $(0.014)$ & $(0.013)$ & & $(0.015)$ & $(0.015)$ & & $(0.015)$ & $(0.014)$ & & $(0.014)$ & $(0.014)$ \\
\hline \multirow[t]{2}{*}{ Sh. of $R \& D$ workers } & & $0.308^{* * *}$ & 0.005 & & $0.277^{\star * *}$ & -0.029 & & $0.240 * \star *$ & -0.064 & & $0.262^{\star * *}$ & -0.046 \\
\hline & & $(0.081)$ & $(0.080)$ & & $(0.083)$ & $(0.083)$ & & $(0.079)$ & $(0.081)$ & & $(0.079)$ & $(0.078)$ \\
\hline \multirow[t]{2}{*}{ Sh. of mgrs } & & & $0.832^{\star * *}$ & & & $0.851^{\star \star *}$ & & & $0.881^{\star \star *}$ & & & $0.868^{\star \star \star}$ \\
\hline & & & $(0.129)$ & & & $(0.127)$ & & & $(0.125)$ & & & $(0.126)$ \\
\hline \multirow[t]{2}{*}{ Sh. of clerks } & & & $0.679 * * *$ & & & $0.684^{\star * *}$ & & & $0.676^{\star \star \star}$ & & & $0.688^{\star \star \star}$ \\
\hline & & & $(0.044)$ & & & $(0.046)$ & & & $(0.044)$ & & & $(0.044)$ \\
\hline \multirow[t]{2}{*}{ Constant } & $7.234^{\star \star \star}$ & $7.235^{\star \star \star}$ & $7.106^{\star * *}$ & $9.214^{\star \star \star}$ & $9.185^{\star \star *}$ & $9.054^{\star * *}$ & $9.577^{\star \star \star}$ & $9.559 * * *$ & $9.428 * \star *$ & $8.456^{\star \star \star}$ & $8.457^{\star \star *}$ & $8.324^{\star \star \star}$ \\
\hline & $(0.064)$ & $(0.065)$ & $(0.063)$ & $(0.068)$ & $(0.070)$ & $(0.068)$ & $(0.067)$ & $(0.069)$ & $(0.067)$ & $(0.064)$ & $(0.066)$ & $(0.064)$ \\
\hline r2_a & .802 & .805 & .819 & .897 & .9 & .906 & .847 & .85 & .86 & .709 & .714 & .735 \\
\hline N.obs. & 16779 & 16758 & 16752 & 16779 & 16758 & 16752 & 16779 & 16758 & 16752 & 16779 & 16758 & 16752 \\
\hline N.firms & 4131 & 4131 & 4131 & 4131 & 4131 & 4131 & 4131 & 4131 & 4131 & 4131 & 4131 & 4131 \\
\hline
\end{tabular}


Table A.2 - Productivity premia with size-specific production function

\begin{tabular}{|c|c|c|c|c|c|c|c|c|c|c|c|c|}
\hline & OLS+DUM & OLS+DUM & OLS+DUM & $\mathrm{OP}$ & OP & OP & LP & LP & $\mathrm{LP}$ & RE-AR1 & RE-AR1 & RE-AR1 \\
\hline \multirow[t]{2}{*}{ MNF } & $0.130^{\star \star \star}$ & $0.186^{\star \star \star}$ & $0.104^{\star \star \star}$ & $0.145^{\text {*** }}$ & $0.053^{\star \star}$ & $0.096^{\star \star \star}$ & $0.204^{\star \star \star}$ & $0.164^{\star \star \star}$ & $0.115^{\star \star \star}$ & $0.157^{\star \star \star}$ & $0.125^{\star \star \star}$ & $0.075^{\star \star \star}$ \\
\hline & $(0.026)$ & $(0.027)$ & $(0.026)$ & $(0.027)$ & $(0.025)$ & $(0.025)$ & $(0.027)$ & $(0.027)$ & $(0.026)$ & $(0.026)$ & $(0.026)$ & $(0.025)$ \\
\hline \multirow[t]{2}{*}{ Exporter } & $0.062^{\star \star *}$ & $0.074^{\star \star \star}$ & $0.052^{\star \star \star}$ & $0.058^{\star \star *}$ & $0.032^{\star *}$ & $0.039 * \star$ & $0.077^{\star \star *}$ & $0.061^{\star \star \star}$ & $0.042^{\star \star \star}$ & $0.073^{\star \star *}$ & $0.060^{\star \star \star}$ & $0.041^{\star \star *}$ \\
\hline & $(0.015)$ & $(0.016)$ & $(0.015)$ & $(0.016)$ & $(0.014)$ & $(0.015)$ & $(0.016)$ & $(0.015)$ & $(0.014)$ & $(0.015)$ & $(0.015)$ & $(0.014)$ \\
\hline \multirow[t]{2}{*}{ Ltd. company } & & & $0.115^{\star \star \star}$ & $0.177^{\star \star \star}$ & $0.081^{\star \star \star}$ & $0.144^{\star \star \star}$ & & $0.167^{\star \star \star}$ & $0.135^{\star \star \star}$ & & $0.138^{\star \star \star}$ & $0.105^{\star \star \star}$ \\
\hline & & & $(0.015)$ & $(0.015)$ & $(0.014)$ & $(0.015)$ & & $(0.015)$ & $(0.014)$ & & $(0.015)$ & $(0.014)$ \\
\hline \multirow[t]{2}{*}{ Product inno } & & & $-0.041^{\star * *}$ & $-0.043^{\star \star *}$ & $-0.039 * * *$ & $-0.042^{\star * *}$ & & $-0.040^{\star \star *}$ & $-0.039 * * *$ & & $-0.039 * * *$ & $-0.037^{\star * *}$ \\
\hline & & & $(0.013)$ & $(0.013)$ & $(0.012)$ & $(0.013)$ & & $(0.013)$ & $(0.012)$ & & $(0.013)$ & $(0.012)$ \\
\hline \multirow[t]{2}{*}{ Process inno } & & & -0.008 & 0.005 & 0.002 & 0.015 & & 0.004 & 0.014 & & -0.004 & 0.006 \\
\hline & & & $(0.012)$ & $(0.012)$ & $(0.011)$ & (0.012) & & $(0.012)$ & (0.012) & & $(0.012)$ & $(0.011)$ \\
\hline \multirow[t]{2}{*}{ Organiz. inno } & & & -0.002 & -0.000 & -0.010 & -0.009 & & -0.001 & -0.010 & & 0.001 & -0.007 \\
\hline & & & $(0.013)$ & $(0.014)$ & $(0.013)$ & $(0.014)$ & & $(0.014)$ & $(0.014)$ & & $(0.014)$ & $(0.013)$ \\
\hline \multirow[t]{2}{*}{ Invest. in mach. } & & & 0.010 & $0.051^{\star *}$ & 0.028 & $0.067^{\star \star \star}$ & & 0.029 & $0.045^{\star \star}$ & & 0.014 & 0.031 \\
\hline & & & $(0.021)$ & $(0.022)$ & $(0.020)$ & $(0.021)$ & & $(0.022)$ & $(0.021)$ & & $(0.022)$ & $(0.020)$ \\
\hline \multirow[t]{2}{*}{ Invest. in info } & & & 0.002 & -0.004 & -0.016 & -0.021 & & 0.005 & -0.012 & & 0.004 & -0.013 \\
\hline & & & $(0.014)$ & $(0.015)$ & $(0.013)$ & $(0.014)$ & & $(0.014)$ & $(0.014)$ & & $(0.014)$ & $(0.013)$ \\
\hline \multirow[t]{2}{*}{ Sh. of R\&D workers } & & & $0.322^{\star \star *}$ & $0.266^{\star * \star}$ & -0.021 & -0.062 & & $0.253^{\star \star \star}$ & -0.077 & & $0.274^{\star * *}$ & -0.060 \\
\hline & & & $(0.078)$ & $(0.082)$ & $(0.079)$ & $(0.083)$ & & $(0.079)$ & $(0.079)$ & & $(0.078)$ & $(0.078)$ \\
\hline \multirow[t]{2}{*}{ Sh. of mgrs } & & & & & $0.919 * * *$ & $1.021^{* \star *}$ & & & $0.983^{\star \star *}$ & & $10.502^{\star \star *}$ & $0.939 * \star *$ \\
\hline & & & & & $(0.123)$ & $(0.122)$ & & & $(0.120)$ & & $(0.066)$ & $(0.121)$ \\
\hline \multirow[t]{2}{*}{ Sh. of clerks } & & & & & $0.773^{\star \star \star *}$ & $0.721^{\star \star \star}$ & & & $0.731^{\star * \star}$ & & & $0.749 * \star *$ \\
\hline & & & & & $(0.045)$ & $(0.046)$ & & & $(0.044)$ & & & $(0.044)$ \\
\hline \multirow[t]{2}{*}{ _cons } & 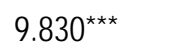 & $11.679 * \star *$ & $9.825^{\star \star *}$ & $11.642^{\star \star \star}$ & $9.678^{\star \star *}$ & $11.499 * * *$ & $10.641^{* * *}$ & $10.618^{\star \star \star}$ & $10.475^{\star \star \star}$ & $10.511^{\star \star \star}$ & & $10.358^{\star \star *}$ \\
\hline & $(0.065)$ & $(0.070)$ & $(0.066)$ & $(0.072)$ & $(0.064)$ & $(0.070)$ & $(0.068)$ & $(0.069)$ & $(0.067)$ & $(0.064)$ & & $(0.064)$ \\
\hline r2_a & .827 & .774 & .829 & .781 & .845 & .798 & .432 & .448 & .493 & .807 & .811 & .827 \\
\hline $\mathrm{N}^{-}$ & 16779 & 16779 & 16758 & 16758 & 16752 & 16752 & 16779 & 16758 & 16752 & 16779 & 16758 & 16752 \\
\hline $\mathrm{N}$ clust & 4131 & 4131 & 4131 & 4131 & 4131 & 4131 & 4131 & 4131 & 4131 & 4131 & 4131 & 4131 \\
\hline
\end{tabular}




\section{Data Appendix}

We match and merge two different datasets: Capitalia's Observatory on Small and Medium Size Firms, a survey on a representative sample of over 4000 Italian firms, and ICE-Reprint, the census of foreign affiliates of Italian firms.

More specifically, we use detailed firm-level data from two Capitalia surveys for the periods 1998-2000 and 2001-2003. Each survey is based on a stratified sample of about 5,000 Italian firms with more than 11 employees, while the sample resulting from the intersection of the two surveys, consist of a panel of approximately 2,000 firms with data from 1998 to 2003. The survey provides information on firms' characteristics, ranging from balance sheet data, to labor composition by worker type (e.g. managers, clerks and production workers) and education attainment, the innovative behaviour (including binary indicators on the realization of process, product and organizational innovation, the engagement and investment in $R \& D$ ), the investment behaviour (including investment in ICT), the internationalization mode.

We matched the Capitalia Suvery data with the census of multinational firms in Italy (ICE-Reprint dataset) ${ }^{19}$,. We label those firms with affiliates abroad in 2001 "Italian multinationals" and we assume that multinational status did not change throughout the period 1998-2003.

Our consolidated dataset provides information on firms' processes of internationalization, economic performance, innovative capacity and growth for up to over 4000 manufacturing firms (depending on the sample used and described in the text this results in between 10000 and 16000 firms-year observations).

Variables definition:

\footnotetext{
${ }^{19}$ The merge of the 2001 version of Reprint with the Capitalia survey is the result of a collaborative effort between ICE and the Centro Europa Ricerche (Cer). Reprint is the directory of Italian multinationals sponsored by ICE (Istituto per il Commercio Estero/Italian Institute for External Trade) and maintained by the Polytechnic of Milan.
} 